\title{
THE INFLUENCE OF LAKES ON THE TOURISM DEVELOPMENT IN UTENA COUNTY
}

\section{EZERU IETEKME UZ TŪRISMA ATTİSTĪBU UTENAS APRIN̦Ķİ Jurgita DAUBARIENE}

\author{
Doctoral student \\ Vilnius University, Department of Hydrology and Climatology \\ M.K.Ciurlionio 21/27, Vilnius LT-2009, Lithuania \\ Phone: +370 68231052; e-mail: jurgita.daubariene@gmail.com
}

\begin{abstract}
The objective of the article is to analyse the influence of lakes on tourism development in Utena County. The tasks of the study are: to define the importance of lakes on tourism development; to review the lake resources of the Utena county; to examine the benefit of lakes for tourism opportunities in Utena county. The article analyses distribution of water bodies and tourism enterprises on the territory of the Utena county. Scientific literature, web sites, legislation on lake tourism and recreational activities on the lakes and on the coasts of lakes were used as references for writing the report.

There are articles dealing with tourism impact on ecosystems of lakes, but so far there have not been any articles that analyse the impact of lakes on tourism development. Therefore, this article is new and topical for Utena county.
\end{abstract}

Keywords: lake, tourism, tourism enterprise, recreation.

\section{Introduction}

Nature-based tourism is one of the most important sectors of Lithuanian tourism industry, and various stakeholders viewed this as having great economic importance. Lakes can be considered as one of the primary resources in nature-based tourism development.

Resource, in the context of tourism, refers usually to the quantity and quality of natural or built environment and public access (Middleton, Hawkins, 1998)(3.).

However, in order to attract tourists, lake tourism destinations must have suitable infrastructure, i.e. water trails and other tourist-related services, which support the use of lakes for touristic purposes. The infrastructure also enhances the development opportunities of tourism businesses. Thus, infrastructure is a central factor in terms of both destination development and development of small tourism enterprises (Goeldner et al. 2000; Lerner, Haber 2000)(2.;5.).

The aim of the article is to analyse the impact of lakes on tourism development in Utena county. 
The tasks of the study are:

1. to define the importance of lakes on tourism development;

2. to review the lake resources of the Utena county;

3. to examine the benefit of lakes for tourism opportunities in Utena county.

A classifier of lakes (Dèl LR ežerų ..., 2003)(1.) and a list of Lithuanian lakes (Lietuvos TSR..., 1964)(4.) were used to examine the lake resources in Utena county. The impact of lakes on tourism is based on the data of the distribution of tourism enterprises by location. The following websites were used for data research: www.utenainfo.lt, www.ignalinatic.lt, www.zarasai.lt, www.antour.lt, www.infomoletai.lt, www.countryside.lt. Legislation on recreational activities was also studied: boating in lakes, underwater fishing, activities in protected areas and others. Analysis method and comparison were used in the survey.

\section{Lakes as tourism resource}

The concept of destination in tourism varies depending on various stakeholders in tourism business. Every destination is a unique whole, in which physical, historical, cultural, social, administrative or functional factors mix in a dynamic way producing a spatial and functional tourism reality. A lake as a tourist destination generally is a functionally compact regional whole with clear geographical limits (Ryhanen, 2003)(8.).

A single lake destination is sometimes surrounded by a compact cluster of tourism activities. A lake destination in some cases is a part of a larger region (Rytu Aukstaitija) where are several small lakes, and the whole region is connected. A lake resort offers tourists various services. Lakes have an aesthetic significance particularly for attracting tourist. Lakes are wellknown tourism destinations at both regional and local levels. Lakes and wetlands are included in the list of tourist attractions on tourism portals of respective states/ cities. Lakes are popular areas set aside for public recreation and the tourists are able to explore every facet of it. Tourists can enjoy scenic journeys around the lake as well as a boat trip.

The lakes declared as water bird sanctuaries are like fairylands for birds. The shorelines or banks of lakes attract both people and a diverse community of plants and animals. The biodiversity of lakes makes them important as natural resources for tourism. Lakes all over the world are used as a resource for ecotourism, natural tourism, leisure tourism and conference tourism and are attracting millions of tourists. Initially lakes served as the only source of drinking water for the town or settlement. Lakes contribute significantly to socio economic development of the surrounding region. 
Lakes provide various benefits that include influencing the microclimate, flood control, encouraging bio-diversity and replenishing groundwater. Lakes act as sewage absorbers in cities, the microclimate of the area surrounding the lake benefits if the lake water level is maintained. The usage of lakes for sports, entertainment, swimming, fishing etc is of great importance to the public. The use of lake shores for residential, commercial development and recreation has increased the world over. Through years of neglect, water has been allowed to deteriorate.

\section{Tourism development near the lakes in Utena county}

\subsection{The lake resources of Utena county}

There are 2833 lakes larger than 0,5 ha in Lithuania. Utena county has $35 \%$ share of all Lithuanian lakes larger than 0.5 ha. (see figure 1 ). There are 1001 lakes.

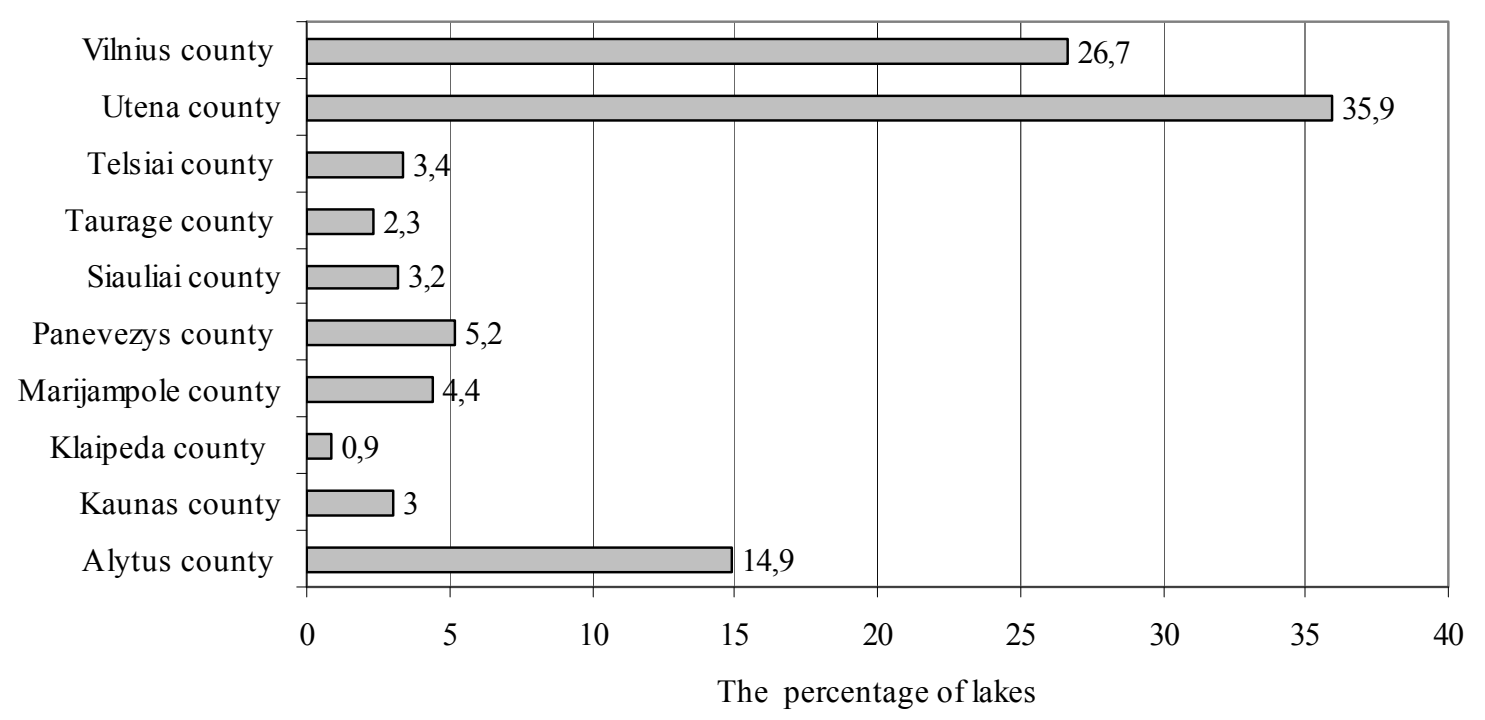

Figure 1. Distribution of lakes on Lithuanian counties

The concentration of separate and connected lakes in Utena county composes the group of lakes. The largest lakes of the region are: Druksiai $\left(44.8 \mathrm{~km}^{2}\right)$ and Dysnai $\left(24.2 \mathrm{~km}^{2}\right)$, the longest lakes - Asveja $(21.9 \mathrm{~km})$, Aisetas $(16 \mathrm{~km})$, Sartai (14.4), the deepest lakes - Tauragnas $(60.5 \mathrm{~m})$, Asveja $(50.2 \mathrm{~m})$, Baltieji Lakajai $(45 \mathrm{~m})$. The largest number of islands is in the Avilys Lake (Zarasai district). The lake is of 1258 ha and has 31 islands. Baluoso Lake situated in Ignalina district is unique. It has several islands and one of the islands has its own internal deep lake. Lake Zarasas is quite attractive for recreation and is located right beside Zarasai city. Antaliepte pond is the compound of 26 lakes with enormous number of lakes and unique configuration of the lakeshore line. These are the lakes that are most popular among water tourists and all of them are most suitable for regular 
and massive tourism development. They are large and attractive enough, and conveniently located to design combined water trails.

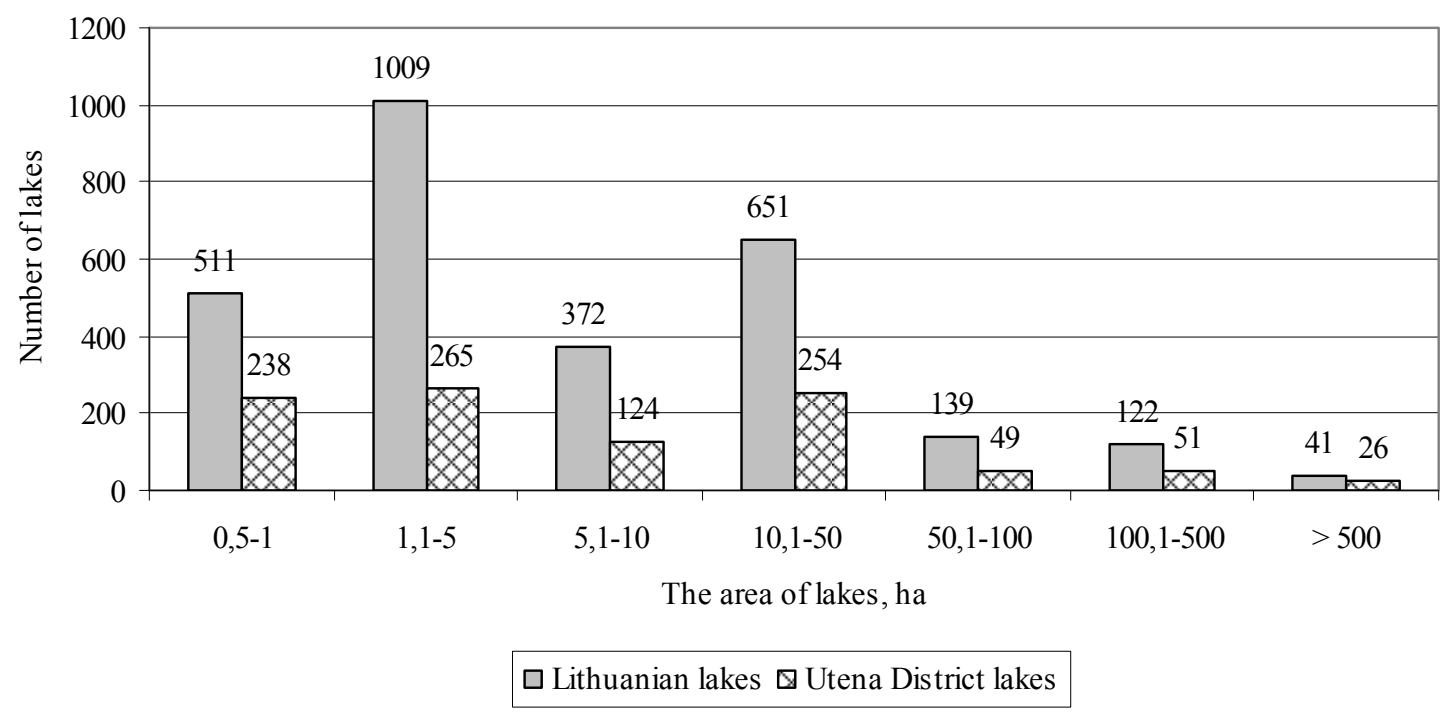

Figure 2. Distribution of different lake areas in Lithuania and in Utena County

Most lakes in Utena county are small lakes, less than 50 hectares (881 lakes). However, there are many larger (larger than 100 ha area) Lithuanian lakes. There are 29 lakes larger than 500 ha in Lithuania. Utena county has 69 \% share of all Lithuanian lakes which are larger than 500 ha. It's very important for the development of recreational activities because the bigger the lake - the greater are the opportunities. On large lakes there are possibilities to organize boating with motorized or non-motorized boats, sailing, swimming, fishing, diving, etc. Recreational activities on large lakes are more diverse and attractive than the ones on small lakes.

\subsection{Use of lakes for tourism in the Utena County}

Utena county is a land of hills, thick forests and picturesque lakes. There are 1001 lakes in the county, more than in any other region of Lithuania. Tourism enterprises (rural tourism, camping, accommodation enterprises, boat rent etc.) are located near 99 lakes. Tourism is being developed near $10 \%$ of the total Utena district lakes (table 1).

There are several concentrations of tourism service providers around the lakes in the region. These service clusters are located on the lakes of Alausas (4 enterprises) and Rubikiai (7) in Anyksciai municipality. In Utena municipality these are the lakes of Alausas (15), Tauragnas (3), Klykiai (4), and Utena pond (3). In Moletai municipality - Baltieji Lakajai, Virinta (4) and Bebrusu (3) lake. In Zarasai municipality these are the lakes of Sartai (12), Luodzio (5) and Antalieptes pond (7). Service providers in Ignalina 
municipality are spread all over the districts among dense concentration of the lakes. Most of them act within the territory of the Aukstaitija National Park.

Number of lakes near which tourism enterprises function

\begin{tabular}{|c|c|c|c|}
\hline \multirow{2}{*}{ Municipality } & \multirow{2}{*}{ Number of lakes } & \multicolumn{2}{|c|}{$\begin{array}{c}\text { Number of lakes, near which are a tourism } \\
\text { enterprises }\end{array}$} \\
\cline { 3 - 4 } & & Units & $\%$ \\
\hline Anyksciai & 77 & 8 & 10,39 \\
\hline Ignalina & 203 & 31 & 15,27 \\
\hline Moletai & 231 & 21 & 9,09 \\
\hline Utena & 185 & 15 & 8,11 \\
\hline Total & $\mathbf{1 0 0 1}$ & $\mathbf{9 9}$ & $\mathbf{9 , 8 9}$ \\
\hline
\end{tabular}

Exceptional water tourism and recreational infrastructure are created on the lakes Laukesa, Siekstis (Zaliasis), Lusiu, Baltieji Lakajai, Alausas, Zarasas, Grabuostas.

The majority of tourism enterprises are concentrated near larger lakes.

Table 2

Rural tourism near lakes

\begin{tabular}{|c|c|c|c|c|c|}
\hline \multirow{2}{*}{ Municipality } & \multirow{2}{*}{$\begin{array}{c}\text { Rural } \\
\text { tourism }\end{array}$} & Units & $\%$ & Bedspace & $\begin{array}{c}\text { Average distance from the lake } \\
\text { to rural tourism farmstead, in } \\
\text { metres }\end{array}$ \\
\cline { 4 - 6 } & 28 & 17 & 60.71 & 493 & 59 \\
\hline Anyksciai & 54 & 50 & 92.59 & 651 & 103 \\
\hline Ignalina & 31 & 29 & 93.55 & 930 & 65 \\
\hline Moletai & 37 & 34 & 91.89 & 783 & 82 \\
\hline Utena & 56 & 55 & 98.21 & 895 & 74 \\
\hline Zarasai & $\mathbf{2 0 6}$ & $\mathbf{1 8 5}$ & $\mathbf{8 9 . 8 1}$ & $\mathbf{3 7 5 2}$ & $\mathbf{7 7}$ \\
\hline Total & & & & & \\
\hline
\end{tabular}

There are 206 rural tourism enterprises in Utena county. 185 rural tourism enterprises (almost $90 \%$ ) are not farther than 500 meters from the lakes. $60 \%$ of the rural tourism is concentrated near the lakes in Anyksciai municipality. Most of the farmsteads in Anyksciai municipality are located near the river Sventoji. Almost $99 \%$ of rural tourism of Zarasai municipality is near the lakes (Table 2).

Most rural tourism places are located on average 77 metres from the lake shores. Rural tourism is located on average 102 metres from the lakes in Ignalina district. It should be noted that 19 rural tourism places of the region are in the Aukstaitija National Park, where the distance from the 
building to the water body is regulated by legislation. All rural tourism providers of Utena district offer boat rental and other water activities.

There are 7 camping sites in Utena district. (Zarasai - 2, Moletai - 3, Utena - 1, Ignalina - 1). All camping sites are near the lakes.

Table 3

Possibilities for boating in the lakes of Utena county

\begin{tabular}{|c|c|c|c|c|}
\hline $\begin{array}{c}\text { Lake } \\
\text { area, ha }\end{array}$ & $\begin{array}{l}\text { Number } \\
\text { of lakes }\end{array}$ & $\begin{array}{c}\text { Percentage } \\
\text { of lakes }\end{array}$ & $\begin{array}{l}\text { Lakes } \\
\text { which } \\
\text { prohibit } \\
\text { boating }\end{array}$ & Possibilities for boating \\
\hline$<10$ & 615 & 61.4 & & - Non-motorized boats \\
\hline $10-200$ & 330 & 33.0 & 2 & $\begin{array}{l}\text { - Non-motorized boats } \\
\text { - Sailing boats } \\
\text { - Motor boats (engine total power } \\
\text { output up to } 4 \mathrm{~kW}(5.4 \mathrm{HP})\end{array}$ \\
\hline $200-500$ & 30 & 3.0 & 2 & $\begin{array}{l}\text { - } \text { Non-motorized boats } \\
\text { - Sailing boats } \\
\text { - } \text { Motor boats (engine total power } \\
\text { output up to } 4 \mathrm{~kW}(5.4 \mathrm{HP} \text { ) } \\
\text { - } \text { Motor boats (engine total power } \\
\text { output up to } 8 \mathrm{~kW}(10.8 \mathrm{HP})\end{array}$ \\
\hline$>500$ & 26 & 2.6 & 4 & $\begin{array}{l}\text { - } \text { Non-motorized boats } \\
\text { - Sailing boats } \\
\text { - } \text { Motor boats (engine total power } \\
\text { output up to } 4 \mathrm{~kW} \text { ( } 5.4 \mathrm{HP} \text { ) } \\
\text { - } \text { Motor boats (engine total power } \\
\text { - } \text { output up to } 8 \mathrm{~kW} \text { (10.8 HP) } \\
\text { - Water motorcycles, water skiing }\end{array}$ \\
\hline
\end{tabular}

There is no research or statistics on water tourist flow in Utena county. Due to abundance of the lakes Utena county receives many holiday makers during the warm season and according to this indicator it falls behind the seaside area only (western part of Lithuania). Nevertheless, it is known that most popular types of boats are baidars, kayaks (70\%) and canoes (20\%) (Rytu Lietuvos, 2003)(7.). These are the most convenient boats for short jaunts as well as for longer trips. Actually, these kinds of boats do not require any special public water tourism infrastructure like slips, quays, except convenient access places from the coast. Water trail infrastructure for these kinds of boats requires camping places and information signs. Other available amatory vehicles on the region lakes are jet boats, water skies, motorboats, pedals, windsurfing boards. These should be treated as the short term recreational equipment. 
Utena county has 386 lakes (40\%) where you can use self-propelled boating means (area more than 10 hectares) and 56 lakes (6\%) (larger than 200 hectares) where you can use more high -powered boats. The exploitation of motor craft boats and water motorcycles is regulated by the State Law and allowed only in midsummer starting from the 1st of July.

Lithuanian legislation on the use of water motorcycles is among the strictest in Europe. The water body must be greater than 500 hectares only then the use of water motorcycles is authorised. There are 41 such lakes in Lithuania. You can use water motorcycles just on 10 lakes larger than 500 hectares. 7 lakes are in Utena county (Druksiai, Dysnai, Avilys, Alausas, Cicirys, Dysnykstis, Galuonu). In the Protected Lake Areas the use of different means of boating is restricted or prohibited.

According to the research of the survey of 20033 tourists, most of the visitors enjoy (Rytų Lietuvos..., 2003)(7.): swimming 68. 3 \%, boating 48. 8 $\%$, fishing $41 \%$

Among other mentioned activities are trekking, mushroom and berry picking. Water trail is a network of access points, resting places and attractions for users of water craft on the lakes. Recreational activities on the water trails are most significant in the whole region. Water trails are or should be a "schoolhouse without walls" which involves the recreational boater and general public into the shore land preservation and stewardship programs. Water trails provide an opportunity for people to explore natural and cultural heritage themselves from a distinctly unique perspective "sitting on" the water. Approximate analysis of tourist flow on the Utena district water trails shows that most popular trails are: Aukstaitija NP lakes 41\%; Sventoji River 18\%; others 35\%.

In fact, these trails are naturally connected and their combination composes an integral water trail network of the region. As for the required infrastructure $59 \%$ of the interviewed water tourists of Utena district evaluated the infrastructure of tourism conditions as good, $38 \%$ - as medium and $3 \%$ were not satisfied. Interviewed respondents noted that simple camping sites are most required. 55\% noted the primary necessity of lodges with well - equipped cottages, and even $90 \%$ pointed particular demand for information infrastructure.

All the waters of lakes in the region are clean enough for recreational activities. Otherwise, in the process of planning of the water-based tourism infrastructure development, all aspects must be precisely measured with the environment protection expertise in terms of hazardousness of the recreational activities growing onto "risky waters" identified by Environmental Agency of Lithuania. All the lakes of the region meet the requirements of these criteria. 
No lake of Utena district can be noted as exceptional in abundance of fish. Nevertheless, recreational fishing is still one of the regions' water-based tourism potential and still remains the niche in the market.

Recreational fisheries are most appropriate to mesotrophic, eutrophic and in part of hypertrophic lakes because they have natural maximum productivity. The area of such lakes is usually greater than 50 hectares. According to Virbickas and Domarkas (2006)(9.) the stocking amateur fishing purposes in small lakes is unreasonable, because you can easily catch the fish with fishing net during a very short period of time. There are 53 lakes of national importance where fishing permits must be issued (an area greater than 50 hectares). These lakes are distributed in 14 counties of the country. Most of these lakes are in Utena county (30 lakes) - in Ignalina (10 lakes), Moletai (10), Utena (5) and Zarasai (5 lakes) districts.

The underwater fishing is allowed on 10 Lithuanian lakes. 8 of them are in Utena county. (Alausas, Antalieptes pond, Asveja, Baltieji Lakajai, Druksiai, Galuonai, Sartai, Siesartis).

\section{Conclusions}

- Utena county has $35 \%$ of all Lithuanian lakes larger than 0.5 ha, $66 \%$ of all Lithuanian lakes are larger than 500 ha.

- Tourism enterprises (rural tourism, camping, accommodation enterprises, boat rental etc.) are near 99 lakes (near $10 \%$ of the total Utena county lakes).

- Utena county has 206 rural tourism enterprises. 185 rural tourism enterprises (almost $90 \%$ ) are not farther than 500 metres from the lakes. In Utena district there are 7 camping sites. All camping sites are near the lakes.

- Tourism enterprise clusters are located at the lakes of Alausas, Rubikiai, Sartai and Antalieptes pond. (41)

- $\quad$ On $40 \%$ of Utena county lakes you can use self-propelled boating means. Utena county has 56 lakes (6\%) where you can use more high powered boats.

- There are 7 lakes where the use of water motorcycles is allowed (the use of water motorcycles is allowed on 10 Lithuanian lakes), 8 lakes where underwater fishing is permitted.

- Due to abundance of lakes Utena County receives many holiday makers during the warm season and according to this indicator it falls behind the seaside area only (western part of Lithuania). Most of the visitors enjoy swimming, fishing and boating.

- It can be concluded that the lakes have a significant impact on the development of tourism in Utena county. 


\section{Bibliography}

1. Dèl LR ežerų klasifkatoriaus patvirtinimo (2003). Lietuvos respublikos Aplinkos ministro įsakymas Nr. 130.. Valstybès žinios. Nr. 34-1442.

2. Goeldner, C. R., Ritchie, J. R. and. McIntosh, R. W (2000). Tourism. Principles, Practises, Philosophies. Eight Edition. John Wiley \& Sons, Inc. New York.

3. Middleton, V. T. and Hawkins, R. (1998). Sustainable tourism: A marketing perspective. Butterworth \& Heinemann. Oxford.

4. Lietuvos TSR ežerų sąrašas su morfometriniais duomenimis (1964). Kaunas: Respublikinis vandens ūkio projektavimo institutas.

5. Lerner, M. and Haber, S. (2000). Performance factors of small tourism ventures: the interface of tourism, entrepreneurship and the environment. Journal of Business Venturing, Vol 16, pp. 77-100.

6. Ranade, P. S. Managing Lake Tourism: Challenges Ahead. Retrieved from: http://dspace.iimk.ac.in/bitstream /2259/599/1/543-554.pdf

7. Rytų Lietuvos vandens turizmo plètros galimybių studija (2003). Retrieved from: http://www.tourism.lt/nsv/index_turizmo_projektai.html

8. Ryhanen, H. (2003). The tourist profile and potential of European lake destinations. Retrieved from: www.joensuu.fi/skk.

9. Virbickas, T. and Domarkas, A. (2006). Vandens telkinių tinkamumas mėgẻjiškai žuvininkystei, rekreacinès žūklès plètra. Lietuvos vidaus vandenu žuvininkystès ir žuvivaisos pletra. pp. 19-21

\section{Summary}

The aim of the article is to analyse the impact of lakes on tourism development in Utena county. The tasks of the study are: to define the importance of lakes on tourism development; to review the lake resources of the Utena county; to examine the benefit of lakes for tourism opportunities in Utena county.

A classifier of lakes (Dèl LR ežeru ..., 2003) and a list of Lithuanian lakes (Lietuvos TSR..., 1964) were used to examine the lake resources in Utena county. The impact of lakes on tourism is based on the data of the distribution of tourism enterprises by location. The following websites were used for data research: www.utenainfo.lt, www.ignalinatic.lt, www.zarasai.lt, www.antour.lt, www.infomoletai.lt, www.countryside.lt. Legislation on recreational activities was also studied: boating in lakes, underwater fishing, activities in protected areas and others. Analysis method and comparison were used in the survey.

According to the research Utena county has $35 \%$ of all Lithuanian lakes larger than 0.5 ha, $66 \%$ of all Lithuanian lakes larger than 500 ha. Tourism enterprises (rural tourism, camping, accommodation enterprises, boat rental etc.) are near 99 lakes (near $10 \%$ of the total of Utena county lakes).

There are 206 rural tourism enterprises Utena county. 185 rural tourism enterprises (almost $90 \%$ ) are not farther than 500 metres from the lakes. There are 7 camping sites in Utena county. All camping sites are near the lakes. Tourism enterprise clusters are located at the lakes of Alausas, Rubikiai, Sartai and Antalieptes pond. (41). On $40 \%$ of Utena county lakes you can use self-propelled boating means. Utena county has 56 lakes (6\%) where you can use more high powered boats. There are 7 lakes where the use of water motorcycles is allowed 
(the use of water motorcycles is allowed on 10 Lithuanian lakes), 8 lakes where underwater fishing is permitted.

Due to abundance of lakes Utena County receives many holiday makers during the warm season and according to this indicator it falls behind the seaside area only (western part of Lithuania). Most of the visitors enjoy swimming, fishing and boating.

It can be concluded that the lakes have a significant impact on the development of tourism in Utena county. 